Eur. J. Clin. Chem. Clin. Biochem.

Vol. 31, 1993, pp. 513-516

(C) 1993 Walter de Gruyter \& Co. Berlin · New York

\title{
A Highly Sensitive Immunoenzymometric Assay for the Determination of Angiogenin
}

\author{
By J. Bläser, Susanne Triebel, C. Kopp and H. Tschesche \\ Department of Biochemistry, University of Bielefeld, Bielefeld, Germany
}

(Received January 11/May 13, 1993)

Summary: A polyclonal antibody to human recombinant angiogenin was prepared in rabbits using a $\mathrm{Pam}_{3} \mathrm{CysSerGly} \mathrm{conjugate.} \mathrm{The} \mathrm{antibody} \mathrm{was} \mathrm{then} \mathrm{used} \mathrm{to} \mathrm{develop} \mathrm{the} \mathrm{first} \mathrm{highly} \mathrm{sensitive} \mathrm{enzyme-labelled}$ immunometric assay for this vascularisation inducing and tumour associated protein. The assay was suitable for quantification of angiogenin in body fluids between 2.5 and $0.05 \mu \mathrm{g} / \mathrm{l}$. The mean intra-assay imprecision was $6.0 \%$ and the inter-assay imprecision $7.9 \%$. Angiogenin in human plasma was found to lie in the range of 0.38 to $0.11 \mathrm{mg} / \mathrm{l}$ with a mean of $0.25 \pm 0.07 \mathrm{mg} / \mathrm{l}$.

\section{Introduction}

Angiogenin is a single chain $M_{\mathrm{r}} 14100$ protein, first isolated and characterised from a HT-29 human adenocarcinoma cell line (1). It has been shown to be an inducer of vascular growth. The protein has $35 \%$ identity with pancreatic ribonuclease (2) and has been shown to inhibit protein synthesis in vitro (3). Saxena et al. described angiogenin as a cytotoxic, t-RNAspecific ribonuclease in the RNase A superfamily (4). Angiogenic and ribonucleolytic activities are blocked by a tight-binding placental ribonuclease inhibitor (5). Recently, it was shown that angiogenin supports endothelial and fibroblast cell adhesion (6). Shapiro et al. isolated angiogenin from human plasma (7). Its mRNA was detected predominantly in the adult liver, but was also detectable at a low level in other tissues (8) and cells (9). Detailed information on the presence of the protein in body fluids and tissues is not available due to the lack of a sensitive and easily performed assay.

Here we report the production of a polyclonal antibody, which was then used to develop the first sensitive immunometric assay for the determination of this protein. The method will facilitate an understanding of the role of angiogenin in physiological and pathophysiological processes.

\section{Materials and Methods \\ Materials}

Nunc Immuno plates II were obtained from Nunc (Roskilde, Denmark). Horseradish peroxidase ${ }^{l}$ ) was obtained from Boehringer Mannheim (Mannheim, Germany) and 2,2'-azino-bis(3ethyl-benzthiazoline-6-sulphonic acid (ABTS) from Sigma (Deisenhofen, Germany). Human recombinant angiogenin was kindly donated by Behringwerke, Marburg. Blood samples were supplied by Prof. Kleesiek, Herzzentrum Bad Oeynhausen.(Bad Oeynhausen, Germany). $S$-[2,3-bis(palmitoyloxy)propyl]-Npalmitoyl-cysteinyl-serinyl-glycine-succinimidyl-ester $\quad \mathrm{Pam}_{3}$ CysSerGlyOSu) and S-[(2RS)-2,3-bis(palmitoyloxy)-propyl]-Npalmitoyl-cysteinyl-lysyl-lysyl-lysyl-lysine (Pam ${ }_{3}$ Cys-Ser-Lys 4 ) were kindly donated by Prof. Jung (Tübingen, Germany).

\section{Methods}

Preparation of the S-[2,3,bis(palmitoyloxy)propyl]-N-palmitoyl-cysteinyl-serinyl-glycine/angiogenin ( $\mathrm{Pam}_{3} \mathrm{C}_{\mathrm{j}}$ SSerGly/angiogenin) conjugate

Recombinant angiogenin $(0.5 \mathrm{mg})$ was mixed with $5 \mathrm{mg}$ $\mathrm{Pam}_{3}$ CysSerGlyOSu in $500 \mu$ freshly distilled dimethylformamide and incubated under continuous stirring for $15 \mathrm{~h}$ at room temperature. After removal of the dimethylformamide, the product was dissolved in $t$-butanol/water $(3+1$, by vol.) and lyophilised (10).

\footnotetext{
1) Enzyme

Horseradish peroxidasc:

donor: hydrogen-peroxide oxidoreductase (EC 1.11.1.7)
} 


\section{Preparation of the antibodies}

$\mathrm{Pam}_{3} \mathrm{Cy}$ sSerGly/angiogenin conjugate $(1 \mathrm{mg})$ was mixed with $0.5 \mathrm{mg} \mathrm{Pam}{ }_{3} \mathrm{CysSerLys}_{4}$ (11), dissolved in phosphate buffered saline and injected into rabbits subcutaneously without additional adjuvants. Further booster immunisations were carried out in the same manner. The antibodies were purified according to the method of Harboe \& Ingild (12) by salting out and ion exchange chromatography on DEAE-Sepharose. The IgG-fraction was used in the assay.

\section{Conjugation of horseradish peroxidase to the $\operatorname{Ig} G$}

The polyclonal IgG was reacted with horseradish peroxidase by a method described by Tijssen \& Kurstak (13).

\section{Tiro-site immunoenzymometric assay}

Microtitre plates were coated with $100 \mu$ antibody at $4{ }^{\circ} \mathrm{C}$ overnight at a concentration of $2 \mathrm{mg} / \mathrm{l}$ in coating buffer ( 50 $\mathrm{mmol} / 1$ sodium carbonate, $\mathrm{pH}$ 9.6). After twice washing with phosphate buffered saline/Tween $(0.2 \mathrm{~mol} / 1$ sodium phosphate, $\mathrm{pH} 7.4,0.15 \mathrm{~mol} / \mathrm{l} \mathrm{NaCl}, 0.5 \mathrm{~g} / \mathrm{l}$ Tween 20) standards and samples were diluted in phosphate buffered saline/Tween containing $10 \mathrm{~g} / \mathrm{l}$ bovine serum albumin and incubated overnight at $4^{\circ} \mathrm{C}$ or for $2 \mathrm{~h}$ at room temperature. Both incubation times gave similar results. After 4 washes with phosphate buffered saline/Tween, $100 \mu$ l of the conjugate solution (IgG/peroxidaseconjugate $1: 2000$ in phosphate buffered saline/Tween containing $10 \mathrm{~g} / \mathrm{l}$ bovine serum albumin) were placed in each well and incubated for another $2 \mathrm{~h}$ at room temperature. After 6 washes with phosphate buffered saline/Tween, the substrate reaction was performed by incubation with ABTS-solution $(1 \mathrm{~g} / 1$ in 0.1 mol/l citric acid, adjusted to $\mathrm{pH} 4.2$ with $\mathrm{Na}_{2} \mathrm{HPO}_{4}, 0.5 \mathrm{~g} / \mathrm{l}$ Tween $20,1.3 \mathrm{mmol} \mathrm{H}_{2} \mathrm{O}_{2}$ ). Absorbance was measured using a Dynatech Microreader MR 4000 (Denkendorf, Germany) at $405 \mathrm{~nm}$. We always used the same antibody for immobilisation and for peroxidase-labelling.

\section{Recovery experiment}

Recovery of angiogenin in plasma. The antigen standards, diluted in $0.2 \mathrm{~mol} / \mathrm{l}$ phosphate-buffered saline/Tween/bovine serum albumin, were added to the prediluted plasma samples. This mixture was serially diluted in 8 steps and analysed by immunoenzymometric assay. Means from those dilutions giving response of $\mathrm{A}_{405 \mathrm{~nm}}$ between 0.2 and 1.5 were selected.

\section{Plasma analysis}

Plasma samples of healthy donors were stored at $-75^{\circ} \mathrm{C}$ until required. A predilution of $1: 100$ was chosen for measurement. All tests, performed twice on two different days, resulted in deviations not above the inter-assay coefficients given in table 1 .

\section{Results}

\section{Production of antibodies}

The $\mathrm{Pam}_{3} \mathrm{CysSerGly/angiogenin} \mathrm{conjugate} \mathrm{in} \mathrm{combi-}$ nation with $\mathrm{Pam}_{3} \mathrm{CysSerLys}_{4}$ as adjuvant was very effective in the production of antibodies in rabbits. Remarkably high titres remained constant for over one year, and more than $0.5 \mathrm{~g}$ of antibody could be gained from one rabbit.

\section{Sensitivity and precision}

The standard curve for angiogenin was used to optimize reaction conditions (fig. 1). The conditions which gave a good change in colour with the change in concentration are given above (fig. 2). Intra-(within)assay run and inter-(between)-run standard deviations (SDs) and coefficients of variation (CVs) are summarised in table 1 . The working range was calculated according to the method of Porstmann \& Kiesig (14). Angiogenin can be assayed in the concentration range between 2.5 and $0.05 \mu \mathrm{g} / \mathrm{l}$. Using plasma from several

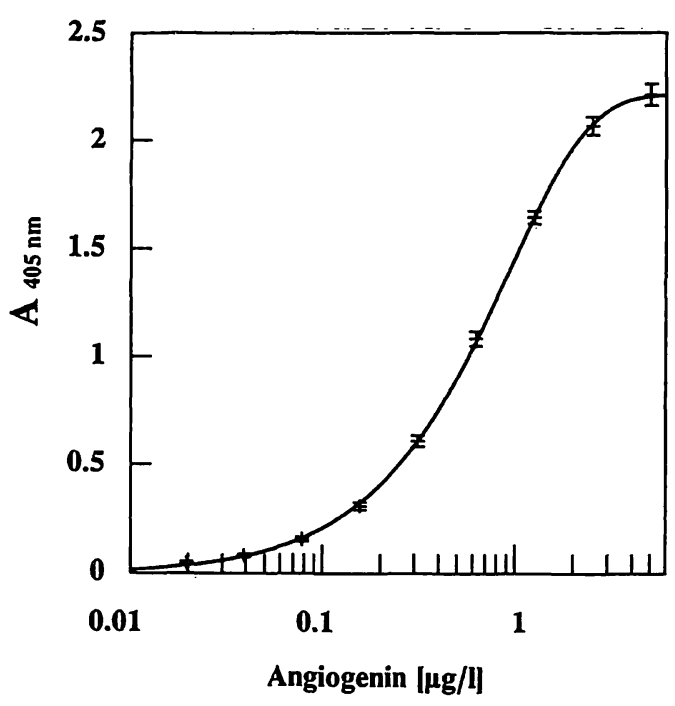

Fig. 1. Standard curve for the sandwich ELISA of angiogenin. The standard curve was determined under optimised assay conditions (see Methods). Standard deviations were calculated from the absorbence values.

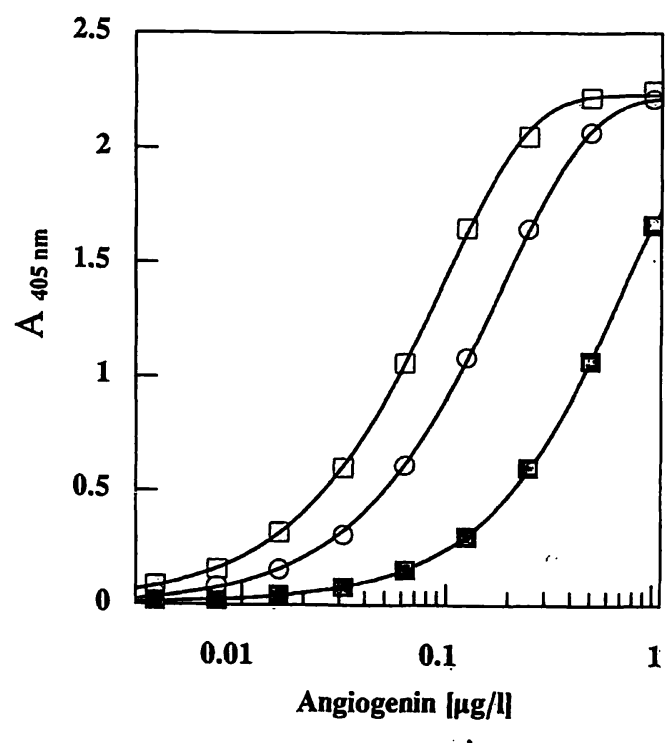

Fig. 2. Standard (O) and sample curves ( $\square$ ) for the sandwich ELISA of angiogenin. All samples were serially diluted in $0.2 \mathrm{~mol} / \mathrm{l}$ phosphate buffered saline/Tween/bovine serum albumin. 
Tab. 1. Precision of the sandwich ELISA for the determination of angiogenin in phosphatase-buffered saline/Tween/ bovine serum albumin. In order to ascertain the precision, profile concentrations were determined from the absorbance values using prediluted plasma samples at different concentrations. These concentrations were used to calculate the standard deviations (SD) and coefficients of variation (CV).

\begin{tabular}{llllll}
\hline $\begin{array}{l}\text { Concen- } \\
\text { tration } \\
(\mu \mathrm{g} / \mathrm{l})\end{array}$ & $\begin{array}{l}\text { Intra-assay } \\
\text { imprecision }\end{array}$ & $\mathrm{n}=8)$ & & \multicolumn{2}{l}{$\begin{array}{l}\text { Inter-assay } \\
\text { imprecision }\end{array}$} \\
\cline { 2 - 3 } \cline { 5 - 6 } & $\mathrm{SD}$ & $\mathrm{CV}$ & & SD & $\mathrm{CV}$ \\
& $(\mu \mathrm{g} / \mathrm{l})$ & $(\%)$ & & $(\mu \mathrm{g} / \mathrm{l})$ & $(\%)$ \\
\hline 1.700 & 0.135 & 7.9 & & 0.145 & 8.5 \\
0.850 & 0.040 & 4.7 & & 0.066 & 7.9 \\
0.425 & 0.023 & 5.4 & & 0.037 & 8.6 \\
0.213 & 0.013 & 6.1 & & 0.014 & 6.5 \\
\hline
\end{tabular}

donors, it was confirmed that the results always showed the same proportional response to dilution in donor plasma and the reference material. Thus, it is acceptable to record results from the reference curve (15). The mean analytical recovery tested for concentrations between 2.5 and $0.16 \mu \mathrm{g} / 1$ was $99 \%$, which was very good for this method.

\section{Determination of angiogenin concentrations in plasma}

In order to determine normal ranges for angiogenin 65 plasma samples from healthy donors were analysed. The measurement was unaffected by repeated freezing of the sample.

Angiogenin in the plasma was found in the range of 0.38 to $0.11 \mathrm{mg} / \mathrm{l}$ with a mean of $0.25 \pm 0.07 \mathrm{mg} / \mathrm{l}$ (fig. 3). There was no significant difference in the concentrations determined in the plasma of female or male donors.

\section{Discussion}

In this paper, we present the first highly sensitive assay for angiogenin. The antibodies prepared by the use of a novel adjuvant were of good affinity and titre. The sensitivity of the assay was about 300 times higher than that of a previously reported assay, which was based on the binding of angiogenin to a placental ribonuclease inhibitor and measurement of its ribonucleolytic activity (16). The ELISA procedure described here is much easier and faster to perform. Angiogenin has $35 \%$ identity with human pancreatic ribonuclease (2). Since this value is not very high, cross-reactivity with this ribunuclease is not to be expected.

Shapiro et al. (7) reported the isolation of angiogenin from human plasma with a yield of $60-150 \mu \mathrm{g} / \mathrm{l}$. From our studies, there is no doubt that they must have lost some protein during their purification procedure. In another paper Bicknell et al. (17) reported a value of $400 \mu \mathrm{g} / 1$ in human plasma without giving the assay procedure or number of samples. Our ELISA procedure represents the first highly reliable routine determination of angiogenin in plasma samples and other body fluids.

Angiogenin is a constituent of normal plasma from healthy donors (7). Its participation as a regulatory component in vascular growth and blood vessel formation is still unresolved, since vascular growth is rapid in the developing rat fetus though angiogenin mRNA levels are low or undetectable (8). Angiogenin may, however, be involved in such processes in adults or during wound healing, since the chick chorioallantoic assay responds to as little as 35 fmol per egg. New blood vessels are formed in the rabbit cornea following application of $3.5 \mathrm{pmol}$ angiogenin (2). Angiogenin may also be a serum $t R$ Nase and it may hydrolyse tRNA-like molecules outside cells, and perhaps also inside cells when such molecules gain entry

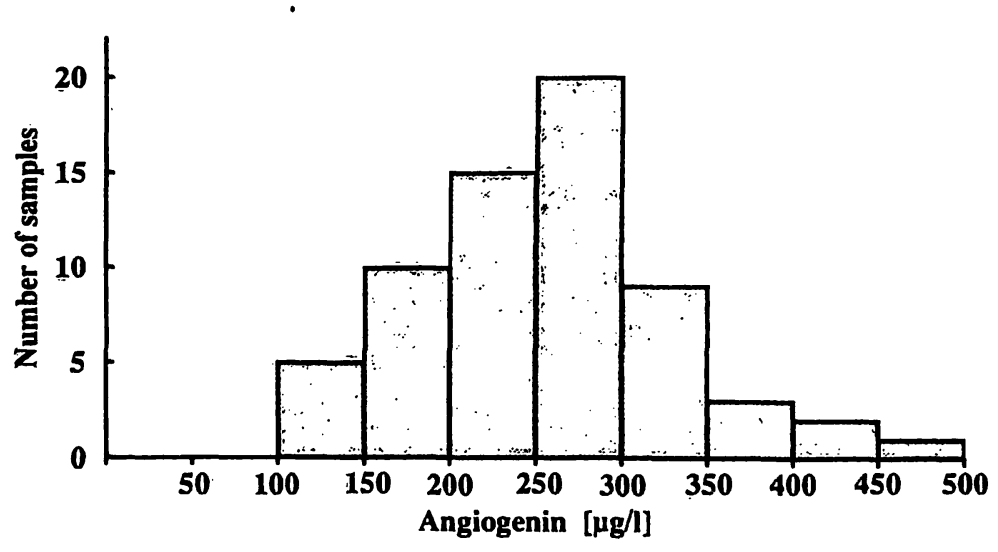

Fig. 3. Distribution of angiogenin in human plasma from healthy donors $(n=65)$. 
during certain physiological or pathological processes. A cytotoxic effect was reported for angiogenin when injected into Xenopus oocytes, and this was related to its cellular tRNase activity (4). Angiogenin activates phospholipase $\mathrm{C}$, elicits a rapid incorporation of fatty acids into cholesterol esters in vascular smooth muscle cells (18), and depresses the concentration of cAMP in aortic smooth muscle cells by a mechanism that is sensitive to pertussis toxin (19).

Since angiogenin is a tumour-derived protein with in vivo angiogenic activity, first isolated from an established human adenocarcinoma cell line (1), it may also serve as a tumour marker for certain malignant

\section{References}

1. Fett, J. W.i Strydom, D. J., Lobb, R. R., Alderman, E. M., Bethune, J. L., Riordan, J. F. \& Vallee, B. L. (1985) Isolation and characterisation of angiogenin, an angiogenic protein from human carcinoma cells. Biochemistry 24, $2480-3486$.

2. Strydom, D. J., Fett, J. W., Lobb, R. R., Alderman, E. M., Bethune, J. L., Riordan, J. F. \& Vallee, B. L. (1985) Aminoacid sequence of human tumor derived angiogenin. Biochemistry 24, 5486-5494.

3. St. Clair, D. K., Rybak, S. M., Riordan, J. F. \& Vallee, B. L. (1987) Angiogenin abolishes cell-free protein synthesis by ribonucleolytic inactivation of ribosomes. Proc. Natl. Acad. Sci. USA 84, 8330-8334.

4. Saxena, K. S., Rybak, S. M., Davey, R. T., Youle, R. J. \& Ackerman, E. J. (1992) Angiogenin is a cytotoxic, tRNAspecific ribonuclease in the RNAs A superfamily. J. Biol. Chem. 267, 21982-21986.

5. Lee, F. S., Shapiro, R. \& Vallee, B. L. (1989) Tight-binding inhibition of angiogenin and ribonuclease by placental ribonuclease inhibitor. Biochemistry 28, 225-230.

6. Soncin, F. (1992) Angiogenin supports endothelial and fibroblast cell adhesion. Proc. Natl. Acad. Sci. USA 89, 2232-223.

7. Shapiro, R., Strydom, D. J., Olson, K. A. \& Vallee, B. L. (1987) Isolation of angiogenin from normal human plasma. Biochemistry 26, 5141-5146.

8. Weiner, H. L., Weiner, L. H. \& Swain, J. L. (1987) Tissue distribution and developmental expression of the messenger RNA encoding angiogenin. Science 237, 280-282.

9. Rybak, S. M., Fett, J. W., Yao, Q. Z. \& Vallee, B. L. (1989) Angiogenin mRNA in human tumor and normal cells. Biochem. Biophys. Res. Comm. 146, 1240-1248. carcinomas. The ELISA established here will provide an important tool for assaying the angiogenin concentrations of plasma, tissues and tissue fluids, in order to correlate its concentration with pathological events.

\section{Acknowledgement}

This work was supported by the Deutsche Forschungsgemeinschaft, special research programme SFB 223, project B1. The authors wish to thank Mrs. V. Süwer and Mrs. N. Balke for skilful technical assistance and Mrs. G. Delany for linguistic advice. We would also like to thank Prof. Dr. B. M. Jockusch and C. Wigand, Faculty of Biology, University of Bielefeld, for taking care of the rabbits during production of the antisera.

10. Wiesmüller, K. H. \& Jung, G., personal communication.

11. Reitermann, A., Metzger, J., Wiesmüller, K. H., Jung, G. \& Bessler, W. G. (1989) Lipopeptide derivatives of bacterial lipoprotein constitute potent immune adjuvants combined with or covalently coupled to antigen or hapten. Biol. Chem. Hoppe-Seyler 370, 343-352.

12. Harboe, N. \& Ingild, A. (1973) Immunisation, isolation of immunoglobins, estimation of antibody titre. Scand. J. Immunol. 2, Suppl. 1, 161-164.

13. Tijssen, P. \& Kurstak, E. (1984) Highly efficient and simple methods for the preparation of peroxidase and active peroxidase-antibody conjugates for enzyme immunoassays. Anal. Biochem. 136, $451-457$.

14. Porstmann, T. \& Kiessig, S. T. (1992) Enzyme immunoassay techniques. J. Immunol. Meth. 150, 5-21.

15. Kemeny, D. M. (1992) Titration of antibodies. J. Immunol. Meth. 150, 57-76.

16. Bond, M. D. (1988) An in vitro binding assay for angiogenin using placental ribonuclease inhibitor. Anal. Biochem. 173, 166-173.

17. Bicknell, R. \& Vallee, B. L. (1988) Angiogenin activates endothelial cell phospholipase C. Proc. Natl. Acad. Sci. USA 85, 5961-5965.

18. Moore, F. \& Riordan, J. F. (1990) Angiogenin activates phospholipase $\mathrm{C}$ and elicits a rapid incorporation of fatty acids into cholesterol esters in vascular smooth muscle cells. Biochemistry 29, 228-233.

19. Xiao, Y., Bicknell, R. \& Vallee, B. L. (1989) Angiogenin depresses aortic smooth muscle cell cAMP by a pertussis toxin sensitive mechanism. Biochem. Biophys. Res. Comm. $163,902-907$.

Prof. Dr. Harald Tschesche

Universität Bielefeld

Fakultät für Chemie

Abteilung Biochemie

Postfach 100131

D-33501 Bielefeld

Germany 